
http://ejurnal.uij.ac.id/index.php/CONS

\title{
PENGEMBANGAN MEDIA ULAR TANGGA DALAM BIMBINGAN KELOMPOK UNTUK MENINGKATKAN PERENCANAAN KARIER
}

\author{
Irfan' $^{1}$, Jarkawi ${ }^{2}$, Eka Sri Handayani ${ }^{3}$ \\ ${ }^{1}$ Mahasiswa Prodi Bimbingan dan Konseling, FKIP, UNISKA MAB, Indonesia \\ ${ }^{2}$ Dosen Prodi Bimbingan dan Konseling, FKIP, UNISKA MAB, Indonesia \\ ${ }^{3}$ Dosen Prodi Bimbingan dan Konseling, FKIP, UNISKA MAB, Indonesia \\ E-mail: 29m.Irfan@gmail.com, jarkawi010462@gmail.com, ekasrihandayani678@gmail.com
}

\begin{abstract}
ABSTRAK
Penelitian bertujuan: Untuk mengetahui bagaimanapengembangan media ular tangga dalam bimbingan kelompok untuk meningkatkan layanan bimbingan dalam bidang karir terhadap perencanaan karier pada siswa SMAIT Ukhuwah Banjarmasin.Penelitian ini menggunakan metode research and development, dari 10 tahapan peneliti menggunakan 5 tahapan menyesuaikan kebutuhan penelitian dengan langkah-langkah sebagi berikut: : (1) Potensi dan masalah. (2) Pengumpulan data. (3) Desain produk. (4) Validasi desain. (5) Perbaikan desain. Penelitian ini dilatar belakangi dengan proses pemberian layanan bimbingan dalam bidang perencanaan karier masih menggunakan media lama (power point) yang bersifat konvensional yang menyebabkan pemberian layanan kurang maksimal dan belum pernah menggunakan media baru apapun. Hasil penelitian ini menunjukkan bahwa media ular tangga dalam bimbingan kelompok untuk meningkatkan layanan bimbingan dalam bidang karir terhadap perencanaan karier pada siswa SMA Islam Terpadu Ukhuwah Banjarmasin layak dan dapat digunakan. Hal ini dapat dilihat dari hasil validasi media yang dinilai oleh Praktisi Guru BK dengan memberikan penilaian di antara $81,0 \%-100,0 \%$ yang artinya sangat valid, dapat digunakan tanpa revisi
\end{abstract}

Kata Kunci: Media Lama, Media Ular Tangga, Perencanaan Karier

\begin{abstract}
The research aims: To find out how the development of snake and ladder media in group guidance to improve guidance services in the career field towards career planning for students of SMAIT Ukhuwah Banjarmasin. This study used the research and development method, from 10 stages the researcher used 5 stages to adjust the research needs with the following steps: (1) Potential and problems. (2) Data collection. (3) Product design. (4) Design validation. (5) Design improvements. This research is motivated by the process of providing guidance services in the field of career planning which still uses conventional old media (power point) which causes service delivery to be less than optimal and has never used any new media. The results of this study indicate that the medium of snake and ladder in group guidance to improve guidance services in the career field of career planning for students of SMA Islam Terpadu Ukhuwah Banjarmasin is feasible and usable. This can be seen from the results of the media validation assessed by counseling teacher practitioners by giving an assessment between $81.0 \%-100.0 \%$ which means very valid, can be used without revision.
\end{abstract}

Keywords: Old Media, Snake and Ladder Media, Career Planning

Dipublikasikan Oleh : Program Studi Bimbingan dan Konseling FKIP Universitas Islam Jember 


\section{PENDAHULUAN}

Sekolah Menengah Atas (SMA) adalah suatu jenjang pendidikan formal yang sangat menentukan bagi para peserta didik sebab peserta didik dituntut untuk menentukan arah masa depan atau karier mereka. Menurut Gibson dalam (Jarkawi dkk, 2017:34) menyatakan bahwa, Sekolah Menengah Atas (SMA) merupakan salah satu jenjang pendidikan formal yang ditempuh oleh siswa dalam mengikuti kegiatan pembelajaran. Pada jenjang ini, siswa berada pada fase memasuki dunia perguruan tinggi atau dunia kerja yang merupakan kesempatan untuk membentuk integritas profesi yang didambakannya.

SMA Islam Terpadu Ukhuwah Banjarmasin, adalah salah satu Sekolah Menengah Atas (SMA) swasta yang ada di Banjarmasin dengan akreditasi A, yang beralamat di Jl. Bumi Mas Raya Komp. Bumi Handayani XII A RT. 28 RW. 02, Kel. Pemurus Baru, Kec. Banjarmasin Selatan, dimana sangat memperhatikan para peserta didiknya terkhusus dalam perencanaan karier seperti menjalin kerja sama dengan pihak Primaga untuk memberikan perencanaan karier dengan menggunakan smart consy berupa pengukuran hasil nilai akademik peserta didik selama di sekolah dengan persyaratan masuk perguruan tinggi dan jurusan yang diingini melalui jalur undangan seperti SNMPTN dan SBMPTN.

Tak hanya itu upaya yang dilakukan Guru BK SMA Islam Terpadu Ukhuwah dalam memberikan layanan bidang karier dengan cara memberikan layanan informasi secara klasikal di dalam kelas dengan masih menggunakan media lama seperti power point atau lembar kerja siswa sebagai sarana penyampaian materi tentang informasi karier, dan juga Guru BK melakukan pemanggilan khusus kepada para peserta didik untuk memberikan layanan dalam bidang karier. Meskipun demikian pemberian layanan dalam bidang karier masih belum optimal sebab didasari dengan peneliti melakukan kegiatan PLP II selama kurang lebih 2 bulan (September-Oktober) peneliti melakukan pengumpulan data. Sugiyono (2016:137) mengatakan teknik pengumpulan data dapat dilakukan dengan wawancara, kuisioner (angket), observasi, dan gabungan ketiganya.

Saat kegiatan PLP II peneliti melakukan penyebaran angket kebutuhan peserta didik (AKPD) untuk mengetahui hasil AKPD jenjang kelas X-XII SMA Islam Terpadu Ukhuwah yang belum memiliki perencanaan karier masa depan. Hasil angket untuk kelas $X$ IIS 1 dari 19 peserta didik ada 7 orang, untuk kelas $X$ IIS 2 dari 22 peserta didik ada 12 orang, untuk kelas $X$ MIA 1 dari 16 peserta didik ada 3 orang, dan untuk kelas X MIA 2 dari 33 peserta didik ada 2 orang. Hasil angket untuk kelas XI IIS 1 dari 28 peserta didik ada 11 orang, untuk kelas XI IIS 2 dari 20 peserta didik ada 5 orang, untuk kelas XI MIA 1 dari 23 peserta didik ada 11 orang, dan untuk kelas XI MIA 2 dari 24 peserta didik ada 11 orang. Hasil angket untuk kelas XII IIS 1 dari 17 peserta didik ada 6 orang, untuk kelas XII IIS 2 dari 13 peserta didik ada 3 orang, untuk kelas XII MIA 1 dari 17 peserta didik ada 7 orang, dan untuk kelas XII MIA 2 dari 24 peserta didik ada 7 orang.

Berbagai fenomena terkait masalah karier tersebut menjadi suatu hal yang sangat penting maka dari itu perencanaan 
karir sangat diperlukan. Perencanaan karier setiap individu merupakan satu hal yang sangat penting saat ini. Perencanaan karier ini dimaksudkan untuk mempersiapkan individu tersebut dalam mengoptimalkan potensi yang dimilikinya. Setiap individu berhak untuk menentukan arah perencanaan kariernya ke depan (Jarkawi dkk, 2017: 123). Maka dari itu hal yang tepat tentunya adalah memberikan bimbingan karier sedini mungkin agar para peserta didik mampu merencanakan kariernya dengan baik.

Pemberian layanan bidang karier untuk perencanaan masa depan juga dapat di lakukan dengan bimbingan kelompok. Menurut Handayani dkk (2018:36) menyatakan bahwa bimbingan kelompok merupakan lingkungan kondusif yang memberikan kesempatan bagi anggotanya untuk menambah penerimaan diri dan orang lain, memberikan ide, perasaan, dukungan bantuan alternatif pemecahan masalah mengambil keputusan yang tepat, dapat berlatih tentang perilaku baru dan bertanggung jawab atas pilihan yang ditentukannya sendiri. Salah satu cara agar bimbingan kelompok mendapatkan hasil yang maksimal yaitu dengan menggunakan media.

Media merupakan salah satu faktor penentu keberhasilan layanan bimbingan dan konseling. Melalui media, pelaksanaan layanan bimbingan dan konseling bisa lebih menarik dan menyenangkan. Aspek penting lainnya penggunaan media adalah membantu memperjelas pesan yang ingin disampaikan dalam bimbingan dan konseling (Nursalim, 2015). Maka dari itu tidak bisa dipungkiri media sangat dibutuhkan perannya dalam pembelajaran atau bimbingan, Salah satu media yang dapat digunakan guru BK sebagai pendukung dalam layanan bimbingan terkhusus dalam bidang karier yaitu media ular tangga.

Nanang Yuliyanto (2016) dalam hasil penelitiannya bahkan menyatakan bahwa media ular tangga juga dapat digunakan dalam administrasi pajak dan layak digunakan sebagai media pembelajaran. Berdasarkan analisis peningkatan motivasi belajar dengan uji $\mathrm{t}$ diperoleh $\mathrm{t}$ hitung $=$ $5,808>\mathrm{t}$ tabel $=1,997$ dan sig $\mathrm{p}=0,000<$ 0,05 . Dengan demikian, media Ular Tangga Administrasi Pajak efektif untuk meningkatkan motivasi belajar. Ikka Nurlita (2017) dalam hasil penelitiannya bahkan menunjukkan bahwa penggunaan media pembelajaran ular tangga juga dapat digunakan dalam pembelajaran aksara jawa edukatif dan berpengaruh terhadap hasil belajar kognitif Bahasa Jawa yang dibuktikan dengan perbedaan rata-rata pemahaman siswa melalui uji t paired sampe/ ditunjukkan dengan t hitung $<\mathrm{t}$ tabel ( $\mathrm{t}$ hitung $=-7,080$ dan $\mathrm{t}$ tabel 2,051) dengan taraf signifikan $0,5 \%$, dan peningkatan rata - rata $\mathrm{N}$-gain sebesar 0,73 dengan kategori tinggi.

Nurul Musa'adah (2017) dalam hasil penelitiannya bahkan menunjukkan bahwa pengujian kelayakan media ular tangga oleh ahli media sebesar $92 \%$ hal tersebut menunjukkan media ular tangga sangat layak untuk diuji cobakan, ahli materi sebesar $81 \%$ dan ahli praktisi sebesar $92 \%$. Hal tersebut menunjukkan bahwa media ular tangga sangat layak untuk diuji cobakan (3) ada perbedaan antara rata-rata nilai IPA materi perubahan lingkungan sebelum menggunakan media ular tangga dan sesudah menggunakan media ular tangga 
ditunjukkan dari nilai thitung $>$ ttabel yaitu $62,17>2,07$

Maka dari itu peneliti akan membuat media ular tangga yang di desain dalam bentuk menginformasikan berbagai profesi karier yang akan dipilih peserta didik di samping itu pada saat pelaksanaan peserta didik dan guru BK akan saling berdialog mengenai informasi profesi karier dengan harapan ketika telah menyelesaikan media permainan ular tangga peserta didik sudah dapat mengetahui atau bahkan mampu menentukan karier yang mereka pilih setelah lulus dari SMA, dan juga di SMA Islam Terpadu Ukhuwah Banjarmasin media ular tangga dalam layanan bimbingan dalam bidang karier belum pernah dilakukan. Berdasarkan latar belakang di atas membuat peneliti memfokuskan penelitian ini pada "Pengembangan Media Ular Tangga Dalam Bimbingan Kelompok Untuk Meningkatkan Perencanaan Karier Siswa SMA Islam Terpadu UkhuwahBanjarmasin"

\section{METODE}

Dalam penelitian ini, peneliti menggunakan desain penelitian metode penelitian dan pengembangan (Research and Development). Sugiyono (2016:297) menjelaskan bahwa metode penelitian dan pengembangan digunakan untuk menghasilkan produk tertentu, dan menguji keefektifan produk tersebut. Penelitian pengembangan lebih diarahkan untuk menghasilkan produk tertentu kemudian diuji keefektifannya sehingga dapat digunakan secara nyata di lapangan. Produk yang dihasilkan dalam penelitian ini adalah "Media Ular Tangga dalam Bimbingan Kelompok untuk Meningkatkan Perencanaan dalam Bidang Karier Pada Siswa SMA Islam Terpadu Ukhuwah Banjarmasin

Pengembangan media ular tangga dalam bimbingan kelompok untuk meningkatkan perencanaan karier siswa SMA Islam Terpadu Ukhuwah Banjarmasin mengadopsi sepuluh tahapan pengembangan menurut Borg and Gall (2003) langkah -langkah yang seyogyanya di tempuh dalam penelitian pengembangan (researchand develompment) meliputi : (1) studi pendahuluan. (2) perencanaan. (3) pengembangan hipotetik. (4) penelaahan model hipotetik. (5) revisi. (6) uji coba terbatas. (7) revisi hasil uji coba. (8) uji coba lebih luas. (9) revisi model akhir. (10) diseminasi dan sosioalisasi.Kemudian langkah-langkah tersebut diartikan di dalam Sugiyono (2016:298) menjadi 10 tahapan tersebut adalah sebagai berikut : (1) Potensi dan masalah. (2) Pengumpulan data. (3) Desain produk. (4) Validasi Desain. (5) Perbaikan Desain. (6) Uji Coba Produk (7) Revisi Produk (8) Ujicoba Pemakaian (9) Revisi Produk (10) Produk Akhir. Namun modelpenelitiandan pengembangan dalam penelitian pengembangan media ular tangga dalam bimbingan kelompok untuk meningkatkan perencanaan dalam bidang karier pada siswa SMA Islam Terpadu Ukhuwah Banjarmasin tidak dilaksanakan sampai tahap produk akhirdikarenakan kebutuhan penelitian dan adanya pandemi covid 19. Batasan prosedur penelitian pengembangan sampai pada tahap kelima yaitu perbaikan desain.

Penelitian pengembangan ini dilakukan di di SMA Islam Terpadu Ukhuwah 
Banjarmasin, Jl. Bumi Mas Raya Komp. Bumi Handayani XII A RT. 28 RW. 02 Kel. Pemurus Baru Kec. Banjarmasin Selatan Kota Banjarmasin Prov. Kalimantan Selatan, 70249

Sumber data dari pengembangan ini terdiri dari Validator Ahli dan Praktisi Guru BK. Validator Ahli memberikan saran dan masukkan terkait tentang pengembangan media ular tangga ini karena di SMA Islam Terpadu Ukhuwah Banjarmasin yang belum pernah menggunakan media ular tangga untuk layanan bimbingan dalam bidang karier terhadap perencanaan karier. Praktisi Guru BK memberikan saran dan masukkan terkait tentang pengembangan media ular tangga ini karena di SMA Islam Terpadu Ukhuwah Banjarmasin belum pernah menggunakan media ular tangga untuk layanan bimbingan dalam bidang karier terhadap perencanaan karier.

Penelitian ini menggunakan teknik pengumpulan data berupa angket. AngketSugiyono (2016:142) angket atau kuesioner adalah sebuah teknik pengumpulan data yang dilakukan dengan cara memberi seperangkat pertanyaan tertulis kepada responden untuk dijawabnya. Maka instrumen ini digunakan untuk menghimpun data selama proses pengembangan media ular tangga dalam bimbingan kelompok untuk meningkatkan layanan bimbingan dalam bidang karir terhadap perencanaan karier. Adapun angket tersebut yaitu angket untuk ahli media atau disebut lembar validasi, angket respon guru, serta angket respon siswa.Lembar validasi digunakan untuk mengetahui tingkat kevalidan media, informasi yang digunakan sebagai masukan dalam merevisi media pembelajaran yang telah dikembangkan sehingga menghasilkan produk akhir yang valid.Adapun data dari angket respon guru dan siswa digunakan untuk mengetahui tingkat keefektifan media dan apakah media ular tangga dapat digunakan dalam proses pembelajaran dan dapat diterapkan oleh guru serta mudah digunakan siswa

Penelitian pengembangan ini menggunakan instrumen pengumpulan data berupa lembar Validasi dan angket. Lembar validasi digunakan untuk memperoleh informasi tentang kualitas media pembelajaran berdasarkan penilaian validator. Informasi yang diperoleh melalui instrument ini digunakan sebagai masukan dalam merevisi media pembelajaran yang telah dikembangkan sehingga menghasilkan produk akhir yang valid. Angket respon guru dan siswa digunakan untuk mengetahui apakah media permainan ular tangga dapat digunakan untuk proses pembelajaran dan dapat diterapkan oleh guru serta mudah digunakan siswa.

Validitas dalam penelian adalah ini adalah validasi ahli dan praktisi. Untuk mendapatkan masukan mengenai kekurangan materi pembelajaran yang menyangkut aspek penilaian materi. Masukan tersebut kemudian dianalisis dan digunakan untuk merevisi materi dalam media pembelajaran sehingga dapat meningkatkan kualitas media pembelajaran yang akan digunakan dalam penelitian. Data validasi ahli dan praktisi materi bimbingan terhadap kualitas aspek penilaian materi bimbingan yang ditunjukkan pada tabel sebagai berikut 


\begin{tabular}{|l|l|}
\hline No & \multicolumn{1}{|c|}{ Aspek Penilain untuk materi } \\
\hline 1 & Desain media sesuai dengan materi perencanaan karier \\
\hline 2 & Desain media sesuai dengan konsep ular tangga dalam perencanaan karier \\
\hline 3 & $\begin{array}{l}\text { Pengemasan media sesuai integrasi materi konsep ular tangga dalam perencanaan } \\
\text { karier }\end{array}$ \\
\hline 4 & Kecukupan materi \\
\hline 5 & Pemilihan warna dalam media \\
\hline 6 & Desain media menarik dilihat \\
\hline 7 & Kecukupan contoh-cotoh yang diberikan \\
\hline 8 & Ketepatan contoh untuk memperjelas isi \\
\hline 9 & Kesesuaian gambar untuk memperjelas materi \\
\hline 10 & $\begin{array}{l}\text { Penyajian media mampu mengembangkan dan meningkatkan perencanaan karier } \\
\text { siswa }\end{array}$ \\
\hline 11 & Tampilan media menarik dan mudah dibawa/ dipindahkan \\
\hline
\end{tabular}

Tujuan adanya validasi adalah untuk mengetahui kelayakan pengembangan media ular tangga. Berdasarkan masukan dari para ahli direvisi untuk membuatnya lebih tepat, efektif, dan memiliki kualitas teknik yang tinggi. Selain itu, instrumen pengumpulan data yang berupa lembar angket respon peserta didik terhadap pengembangan media ular tangga dalam bimbingan kelompok untuk meningkatkan perencanaan dalam bidang karier juga ikut divalidasi oleh validator ahli dan praktisi.

Reliabilitas dalam penelitian ini adalah ukuran yang menunjukkan seberapa tinggi suatu instrument dapat dipercaya atau diandalkan untuk digunakan sebagai alat pengumpul data karena instrument tersebut sudah baik, instrument yang digunakan berupa angket

Pengukuran keabsahan data pada penelitian pengembangan ini yaitu dengan menggunakan kuesioner dan uji validitas. Kuesinor adalah teknik ini dilakukan dengan cara memberikan pertanyaan berupa soal kepada siswa setelah menggunakan media ular tangga, sedangkan uji validitas dilakukan untuk mengetahui kevalidan dari suatu insturmen. Instrumen yang tidak valid berarti tidak dapat mengukur apa yang akan diukur sehingga hasil yang didapat tidak dapat dipercaya dan apabila ada item yang tidak valid harus diperbaiki

Teknik analisis data pada penelitian ini adalah Analisis Validasi Ahli dan Praktisi. Data validasi para ahli dan praktisi kemudian dianalisi secara deskriptif, yaitu tinjauan dan saran dari ahli materi dan ahli media sesuai dengan prosedur pengembangan yang dilakukan. Tahap awal peneliti mencari potensi dan masalah agar dapat mengetahui media apa yang akan dikembangkan, kemudian setelah mengetahui media yang dikembangkan berupa media ular tangga untuk perencanaan karier maka dilakukan proses pengumpulan referensi mengenai informasi seputar karier, tahap selanjutnya yaitu penyusunan instrumen penelitian dan 
pengembangan media. Tahap terakhir adalah penilaian. Media ini divalidasi oleh ahli materi dan ahli media. Setelah divalidasi oleh ahli materi dan ahli media, media kemudian direvisi sehingga diperoleh media revisi tahap I. Media hasil revisi tahap I kemudian diujicobakan dengan cara digunakan oleh Guru BK pada saat pemberian layanan bimbingan dalam bidang karier, maka akan dihasilkan produk media ular tangga untuk layanan bimbingan dalam bidang karier terhadap perencanaan karier pada siswa SMA Islam Terpadu Ukhuwah Banjarmasin

\section{HASIL DAN PEMBAHASAN}

Hasil

penelitian

dalam

pengembangan media ular tangga untuk layanan bimbingan dalam bidang karier terhadap perencanaan karier siswa kelas SMA Islam Terpadu Ukhuwah Banjarmasin,dalam pelaksanaannya menggunakan 5 Tahapan yaitu:

1. Potensi dan Masalah

Proses pemberian layanan bidang karier dengan cara memberikan layanan informasi secara klasikal di dalam kelas dengan masih menggunakan media lama seperti power point atau lembar kerja siswa sebagai sarana penyampaian materi tentang informasi karier, dan juga Guru BK melakukan pemanggilan khusus kepada para peserta didik untuk memberikan layanan dalam bidang karier masih bersifat konvensional menyebabkan pemberian layanan kurang maksimal dan belum pernah menggunakan media baru apapun untuk pemberian layanan bimbingan untuk meningkatkan perencanaan karier.

2. Pengumpulan Data
Pengumpulan data dengan menyebar AKPD kepada siswa untuk mengetahui yang belum memiliki perencanaan karier,Hasil angket untuk kelas $X$ IIS 1 dari 19 peserta didik ada 7 orang, untuk kelas $X$ IIS 2 dari 22 peserta didik ada 12 orang, untuk kelas $X$ MIA 1 dari 16 peserta didik ada 3 orang, dan untuk kelas X MIA 2 dari 33 peserta didik ada 2 orang. Hasil angket untuk kelas XI IIS 1 dari 28 peserta didik ada 11 orang, untuk kelas XI IIS 2 dari 20 peserta didik ada 5 orang, untuk kelas XI MIA 1 dari 23 peserta didik ada 11 orang, dan untuk kelas XI MIA 2 dari 24 peserta didik ada 11 orang. Hasil angket untuk kelas XII IIS 1 dari 17 peserta didik ada 6 orang, untuk kelas XII IIS 2 dari 13 peserta didik ada 3 orang, untuk kelas XII MIA 1 dari 17 peserta didik ada 7 orang, dan untuk kelas XII MIA 2 dari 24 peserta didik ada 7 orang, kemudian peneliti mencari informasi yang dapat digunakan sebagai bahan untuk perencanaan, dengan wawancara, diskusi dengan guru BK dan bahan literatur seperti jurnal.

\section{Desain Produk}

Desain produk berupa media ular tangga untuk meningkatkan layanan bimbingan dalam bidang karir terhadap perencanaan karier.

4. Validasi Desain

Validasi desain adalah proses meminta penilaian terhadap ahli setelah desain produk dibuat, peneliti meminta validasi desain kepada validator ahli media untuk memintapenilaian kelayakan produk kepada validator ahli, validator ahli media memberikan Setelah desain produk dibuat, peneliti meminta validasi desain kepada validator ahli media untuk meminta penilaian kelayakan produk kepada validator ahli, 
validator ahli media memberikan penilaian di antara 41,0 \% - 60,9 \% yang artinya kurang valid, disarankan tidak digunakan karena perlu revisi besar.

\section{Perbaikan Desain}

Proses perbaikan desain setelah mengetahui hasil, saran dan perbaikandari validator ahli media kemudian media perbaiki, setelah media diperbaiki peneliti meminta penilaian kelayakan produk kepada Validator ahli media lagi dan Praktisi Guru BK, setelah dilakukan perbaikan validator ahli media memberikan penilaian $61,0 \%$ $80,9 \%$ yang artinya media yang digunakan cukup validdan Praktisi Guru BK memberikan penilaian diantara $81,0 \%-100,0 \%$ Sangat valid, dapat digunakan tanpa revisi

Dari hasil penilaian menunjukan bahwa pengembangan media ular tangga dalam bimbingan kelompok untuk meningkatkan perencanaan karier siswa SMA Islam Terpadu Ukhuwah Banjarmasin dapat digunakan. Ini sesuai dengan fungsi media sebagai salah satu faktor penentu keberhasilan layanan bimbingan dan konseling. Melalui media, pelaksanaan layanan bimbingan dan konseling bisa lebih menarik dan menyenangkan. Aspek penting lainnya penggunaan media adalah membantu memperjelas pesan yang ingin disampaikan dalam bimbingan dan konseling (Nursalim, 2015).

\section{SIMPULAN}

Berdasarkan hasil penelitian dan pembahasan dapat diambil beberapa kesimpulan yakni :

1. Proses pemberian layanan informasi dalam bidang perencanaan karier masih secara klasikal dengan menggunakan media lama (power point) bersifat konvensional menyebabkan pemberian layanan kurang maksimal yang didasari dengan hasil AKPD,

2. Belum pernah menggunakan media baru untuk proses pemberian layanan dalam bidang perencanaan karier

3. Telah dihasilkannya media ular tangga dalam bimbingan kelompok untuk meningkatkan perencanaan dalam bidang karier pada siswa SMA Islam Terpadu Ukhuwah Banjarmasin

Implikasi atau kegunaan dari produk yang telah dikembangkan ini dapat bermanfaat untuk SMA Islam Terpadu Ukhuwah Banjarmasin terkhusus Praktisi Guru BK sebagai altertanif dalam memberikan layanan bimbingan dalam bidang karier terhadap perencanaan karier siswa.

Berdasarkan hasil penelitian, pembahasan, dan kesimpulan yang diperoleh maka peneliti mengajukan saran sebagai berikut:

1. Untuk Guru BK SMA Islam Terpadu Ukhuwah Banjarmasin, diharapkan media yang telah dibuat ini dapat diaplikasikan dalam memberikan layanan bimbingan dalam bidang karier terhadap perencanaan karier siswa

2. Untuk Siswa, diharapkan mampu memberikan manfaat untuk membantu siswa dalam merencanakan karier masa depannya dan menjadikan siswa lebih aktif saat pemberian layanan 
3. Untuk Sekolah, diharapkan dengan penelitian ini mampu bermanfaat dan dapat diaplikasikan bagi sekolah

4. Kepada peneliti selanjutnya, diharapkan dapat meneruskan penelitian ini, ataupun dapat mengembangkan media ular tangga tersebut agar dapat dibakukan sebagai media dalam bimbingan dan konseling

\section{DAFTAR PUSTAKA}

Husna, Lailatul, Eka Sri Handayani dan Farial. (2018). Pengaruh Layanan Bimbingan Kelompok dalam Meningkatkan Minat Belajar Siswa Kelas IX di MTs Nurul Falah Juai Kabupaten Balangan. Jurnal Mahasiswa BK An-Nur : Berbeda, Bermana, Mulia, 4(1), 36.

Gall, Meredith D.Gall Joyce P. \& Borg, Walter R, (2003). Educational Research.An Introduction, Seventh Edition. Boston: Pearson Education Inc.

Ikka Nurlita (2017). Pengembangan Media Pembelajaran Ular Tangga Aksara Jawa Eduktif Dalam Meningkatkan Hasil Belajar Bahasa Jawa Siswa Kelas IV SD Negeri Sekaran 02 Semarang. Skripsi Universitas Negeri Semarang Jarkawi, Akhmad Rizkhi Ridhani, dan Didi Susanto. (2017). Strategi Bimbingan dan Konseling Karier Bermutu pada Sekolah Menengah Kejuruan Syuhada Banjarmasin. Jurnal Kajian Bimbingan dan Konseling, 2(3). 123.
Jarkawi, Ana Diniati dan Farial. (2017). Layanan Bimbingan Kelompok dalam Mengurangi Kecanduan Anak yang Menggunakan Gadget Di SMK Negeri 1 Paringin. Jurnal Mahasiswa BK AnNur : Berbeda, Bermana, Mulia, 3(3),

Jarkawi, Eka Sri Handayani dan Yulianoor. (2017). Layanan Informasi dengan Media Bingka Karier Untuk Meningkatkan Pemahaman Diri dalam Memutuskan Karier Siswa Kelas XI IA 1 di SMAN 1 Alalak Kabupaten Batola. Jurnal Mahasiswa BK An-Nur : Berbeda, Bermana, Mulia, 3(3), 34.

Nanang Yulianto. (2016). Pengembangan Media Pembelajaran Ular Tangga Untuk Meningkatkan Motivasi Belajar Siswa Pada Mata Pelajaran Administrasi Pajak Kelas XI Akuntasi SMK Negeri 1 Klaten Tahun Ajaran 2015/2016. Skirpsi Universitas Negeri Yogyakarta

Nursalim, Mochammad.

Pengembangan Media Bimbingan Dan Konseling. Jakarta. Indeks

Nurul Musa'adah.(2017),Pengembangan Media Ular Tangga Pembelajaran Ipa Materi Perubahan Lingkungan Kelas IV SDN Demaan Rembang. Skripsi Universitas Negeri Semarang

Sugiyono. (2016), Metode Penelitian Kuantitatif, Kualitatif, dan R\&D. Bandung. Alfabeta Bandung 